of independence. That is why the first need is for an agricultural extension service ready to hold the hands of newly independent farmers. The snag, of course, is that creating such institutions will take more time than Gorbachev can spare.

\section{Summit technology}

Next week's summit in Paris should pay more attention than planned to the benefits of technology.

WHAT can the heads of seven governments (Britain, Canada, France, Italy, Japan, West Germany and the United States) usefully do to make the world a tidier place? They have one obvious task, that of plotting a course towards a more stable economic system, as the Organization of Economic Cooperation and Development (OECD) has been helpfully reminding them this week. Inflation, the bugbear ten years ago, is now again so much a threat that some observers have begun pleading that even a recession would be welcome. There are two obvious objections.

At least in the short run, a recession would impede the Bush administration from cutting the federal budget deficit in the United States, itself one of the engines of inflation internationally. And a general recession now would further damage two of the important but unrepresented interests at next week's meeting - the poor countries of the world would again be disappointed, while brave hopes now current that the future may be brought about benignly would be attenuated as governments cut back on innovation and improvement.

Economists will say that the summit meeting could take two useful steps to avoid recession while keeping inflation down - resolve on further steps towards monetary coordination and to the liberalization of international trade. The usual communique will no doubt offer the usual promises, but the summit governments could usefully try on this occasion to be more imaginative. When the same governments last met in France, in 1982, they were startled that President François Mitterrand should have made technology the centrepiece of the agenda. He then, like the rest of them then and now, was seeking to harness science and technology more directly to social benefit.

It would be a pity if the summit perpetually ignored the essence of the old Mitterrand argument. There are two simple limitations of the benefits that may flow from science and technology: the limited stock of learning and skill, and the tendency for it to be occupied (often at the behest of governments) on fruitless projects. 'This argues both for collaboration (which, in the market-driven West, means the mobility of people) and that choices should be made by the potential beneficiaries rather than by governments, which are not always the best proxies for them. The most serious threat to this opportunity is the tendency for governments to regard technology as an instrument of national chauvinism. It is time they stopped.

\section{Revolution in France}

Whatever the failures of the revolution 200 years ago, it seems to have left French science unscathed.

NeXt Friday's Bastille Day will be the second centenary of the French Revolution, but will also see the opening in Paris of this year's summit meeting between the heads of state of the seven major industrialized countries of the West. The coincidence is not accidental. At some early stage in the planning of the summit, President François Mitterrand was evidently keen that others should not forget the glorious history of France. In the event, he, those who live in Paris and the military bands that play patriotic music throughout Bastille Day may regret the traffic jams the coincidence will certainly create.

But Mitterrand's gesture is well calculated. There are aspects of the French Revolution that may be overlooked despite the welter of retrospection in which historians have been engaged for the past year and more. Not that the historians' interests are a bore. It remains a matter of fascination that a revolution born of enlightenment (almost literally of the Enlightenment, as encapsulated in Diderot's great Encyclopédie) or even of naive idealism (Rousseau), should so quickly have been succeeded by the Terror (in which Lavoisier among others was executed, in 1794) and that the man appointed to carry the revolution to the rest of Europe (Napolcon) should have founded an empirc instead. What the historians have not been saying is also interesting: little has recently been heard of the once-fashionable theme that the apotheosis of the ostensible failure of the French Revolution is to be found in Lenin's later exploits, for they scem also to have been a disappointment.

What those who are not French may easily forget is that the revolution sprang not just from social discontent, but from a tradition of rationality going back at least to Descartes, Newton's older contemporary. Seventeenthand eighteenth-century France was also lucky that two of its strongest social institutions, the Army and the Church, provided means by which able people could practise science, the former by the military colleges that becamo the grandes écoles. The revolution's leading scientist, Laplace, brilliantly united the cartesian and newtonian traditions, but also had the grace to writc a popular book on the subject with the breathtaking title Exposition $d u$ Systéme du Monde. Lavoisicr may have literally lost his head, but his contemporaries and successors, Berthellot for example, kept the flag of rationality flying. Lamarck, now generally scorned, had the wit to spell out that natural evolution is a real process, but the children of the revolution included Pasteur (born in 1822), without whom our own century would have begun impoverished. These traditions would hardly have survived the revolution had not they been part of it, but President Mitterrand will be well within his rights if, next weekend, he boasts about it a little to his guests. 